Jeffrey Friedman

THE LIBERTARIAN STRADDLE: REJOINDER TO PALMER AND SCIABARRA

\begin{abstract}
Palmer's defense of libertarianisin as consequentialist runs afoul of his own failure to provide any consequentialist reasons for libertarian conclusions, and of his own defense of nonconsequentialist arguments for the intrinsic value of capitalism-cum-negative freedom. As such, Palmer's article exemplifies the parasitic codependency of consequentialist and nonconsequentialist reasoning in libertarian thought. Sciabarra's defense of Ayn Rand's libertarianism is even more problematic, because in addition to the usual defects of libertarianism, Rand adds a commitment to ethical egoism that contradicts both her concern for the consequences of capitalism and her commitment to the rights of everyone, not just herself.
\end{abstract}

Tom G. Palmer's Reply (1998b) to "What's Wrong with Libertarianism" (Friedman 1997) is useful in affirming the thesis of my article, as much by virtue of its failure to deal with the substance of my arguments as by its object demonstration of the workings of the "libertarian straddle" I identified. So-wherever possible confining to end notes rejoinders to Palmer's accusations and misreadings ${ }^{1}$ - I will concentrate here on what is missing from his Reply: any solution to the conundrum I set forth in "What's Wrong with Libertarianism." I will also take the opportunity to point out some problems with Chris Matthew Sciabarra's more civilized response to my article, while underscoring evi-

Critical Review 12, no. 3 (Summer 1998). ISSN 0891-3811. Q 1998 Critical Review Foundation.

The editor thanks Justin Weinberg for comments. 
dence in Richard Epstein's, Edward Feser's, and Am Feallsanach's articles of the widespread and damaging effects of the libertarian straddle.

Libertarianism, I maintained, yokes together two disparate kinds of reasoning, consequentialist (or "teleological") and nonconsequentialist (or "deontological"). The first is the province of free-market economists and other social scientists, who contend that laissez-faire capitalism produces desirable consequences. The second is the realm of libertarian philosophers, who contend that because of its intrinsic justice, laissez faire is desirable a priori, regardless of its consequences. These two kinds of reasoning render each other superfluous. If libertarian philosophy is valid, there is no need to investigate the empirical consequences of laissez faire. And if the a posteriori consequences of laissez faire need to be investigated, then there is no need for a priori libertarian philosophy.

However, I argued, nonconsequentialist libertarian philosophy not only renders libertarian social science superfluous, it positively undermines its validity - unless we are to believe that divine providence has so ordered the universe that the same libertarian institutions that are, according to empirical social science, instrumental to "peace, prosperity, cooperation, knowledge, social harmony, etc." (Palmer I998b, 34I) also happen to be the institutions that philosophers know (prior to any empirical research) are intrinsically just. While it is, of course, conceivable that sound consequentialist and nonconsequentialist reasoning could independently produce libertarian conclusions, this result is so unlikely that it raises the possibility-which I confirmed through an analysis of several recent libertarian works-that libertarian social science is, as currently practiced, an ideological tool designed, as it were-although subconsciously-to buttress philosophically preordained conclusions. The ideological function of libertarian social science stems from its practitioners' implicit belief that laissez-faire capitalism is intrinsically just. In parallel fashion, the ideological function of libertarian philosophy stems from its practitioners' implicit assumption that libertarian social science delivers an a posteriori case for laissez-faire capitalism. The symbiosis of libertarian philosophy and social science is the "libertarian straddle."

Palmer maintains that I suggested that the libertarian straddle is the result of a "conspiracy" among libertarians (Palmer 1998b, 339, 344), but of course I did not. It is a matter not of conspiracy, but of the way the human mind naturally tends to use any means at its disposal to defend its ideological commitments. 
Nor is it true, as Palmer contends, that the convergence of philosophy and social science upon libertarian conclusions can be accounted for by the fact that both approaches study the same subject. The reality is that philosophy and social science do not study the same subject, in any but the most trivial sense. Yes, both philosophy and social science study "humanity" (Palmer 1998b, 340); but social scientists investigate what is and has been done by humanity; moral philosophers think about what should be done.

Moral philosophy need not, however, be completely disconnected from what is and has been done. It is true that if one decides that certain social arrangements-such as the right to possibly unequal amounts of private property-are intrinsically valuable (perhaps as expressions of individual rights or of freedom), one need have no recourse to social science in assessing the legitimacy of those arrangements. The conclusion is formed in the silence of the philosopher's study: the social arrangements in question are considered ends in themselves. But if one decides that ends such as happiness or beauty are intrinsically valuable, then one will need to go out into the world and undertake empirical research to try to determine which social arrangements are instrumental to those ends.

The second type of moral philosophy is the type I was calling for. But the unfortunate fact is that libertarian philosophers do routinely proclaim the justice of laissez-faire capitalism not on the basis of its empirical effects, but on the basis of its alleged instantiation of individual rights or freedoms. How, then, in the absence of supernatural intervention, are we to account for the convergence of their views with those of the social scientists who make similar proclamations, but based on the study of the empirical effects of capitalism?

Palmer evades this question by ignoring the way libertarian philosophy is actually practiced. Unwittingly adopting as his own precisely the ideal that I articulated in "What's Wrong with Libertarianism"2 - the consequentialist (or hypothetical-imperative) approach that would rely, for its political recommendations, on the results of empirical researchPalmer claims that this is the approach libertarian philosophers already take. Yet the "libertarians" Palmer adduces in support of this claimAristotle, Aquinas, Grotius, Pufendorf, Locke, Smith, and Hume-were not, in fact, libertarians. And Palmer's other example, Hayek, not only failed to oppose all state intervention in the market, as libertarians do; his opposition to most intervention invariably smuggled in nonconsequentialist considerations. For instance, as Feser's article in this issue of 
Critical Review makes clear, Hayek laid enormous emphasis on the argument that since "injustice" is commonly thought to require intentional action by some agent, and since market outcomes are not determined by such actions, market outcomes cannot be called "unjust." But this purely linguistic argument has nothing to do with the alleged empirical consequences of the free market. (It also fails as nonconsequentialist philosophy, since a set of outcomes need not be "unjust" for it to be undesirable and thus the object of reform.) Similarly, Hayek assumes that the coercive imposition of a value such as equality is inherently objectionable, regardless of economic or other consequences; the only value to which such an assumption would not apply is liberty-making liberty categorically, not hypothetically, valuable. In these ways, and in his version of the rule of law (see Williams 1997), Hayek tries to close the case against egalitarian redistribution a priori-without regard to whether markets produce more prosperity or other "goods" than central planning does.

Thus, there is quite a gulf between the "libertarian" philosophers Palmer cites and the hypothetical-imperative libertarianism he now embraces. Meanwhile, Palmer's Reply never mentions actual libertarian philosophers, such as Robert Nozick, Murray Rothbard, Jan Narveson, and Loren Lomasky. The standard works of these authors are nothing if not categorical, and empirical considerations are almost entirely absent from them. ${ }^{3}$ Palmer may wish things were different, and I certainly do, but wishing won't make it so.

What would make it so, I argued, is for libertarians to stop straddling the line between consequentialism and nonconsequentialism. To encourage them to get off the fence and, moreover, to choose consequentialism over nonconsequentialism, or teleology over deontology, or hypothetical over categorical imperatives, I traced the roots of libertarianism to the Enlightenment project that produced the discipline of economics, ${ }^{4}$ suggesting that nonconsequentialism is a betrayal of the origins of libertarianism and, more importantly, a betrayal of the origins of sensible libertarians' own commitment to their creed. Libertarians tend to think libertarianism would be good for people, because (they believe) it would make for a more prosperous, less contentious, more peaceful, less frustrating society. If this is why one is a libertarian, it should be the basis on which one theorizes and argues for her creed. But theories and arguments grounded on the good consequences of libertarianism will have to be tentative as well as hypothetical-because they will depend on ever-changing empirical research into whether lib- 
ertarianism really would be good for people. To escape this uncertainty, it is tempting to make libertarianism into a free-standing philosophical doctrine based on the inherent justice of laissez faire-turning one's back on the disputable real-world consequences that drew the libertarian to her doctrine in the first place.

The conundrum outlined in "What's Wrong with Libertarianism"the tension between a priori, "philosophical" and a posteriori, "empirical" approaches to libertarianism-was intended to explain the stark fact that libertarian social science is not, at present, any more tentative and hypothetical than libertarian philosophy is consequentialistic. As with my evidence for the nonconsequentialist nature of libertarian philosophy, Palmer ignores the evidence I presented for the dogmatism of libertarian social science. Any nonlibertarian who is familiar with libertarian thought will be astonished at the Panglossian quality of Palmer's depiction of it.

Those who are not familiar with libertarianism, however, need only look at the other article in this issue by Palmer (I998a), as well as those by Epstein and Feallsanach, to see how distorted is the picture of libertarianism Palmer gives in his Reply to me (1998b). These other articles each dispute G. A. Cohen's argument that self-ownership does not necessarily issue in a libertarian form of "world-ownership." This is part of Cohen's larger project of disabusing libertarians of the habit of unquestioningly equating their political conclusions with the values they consider desirable: not only self-ownership, but freedom. Thus, Cohen is attacking the simplistic means by which nonconsequentialist libertarianism is frequently vindicated; the philosophical equation of libertarianism with self-ownership and freedom that he questions is completely independent of the empirical consequences of libertarianism in the real world. In rebutting Cohen, Palmer is, like Epstein and Feallsanach, defending nonconsequentialist libertarianism, contrary to Palmer's assertion that libertarian philosophy is consequentialist.

Yet in the course of their defenses, all three authors appeal to Locke's claim that unless property could be individuated, human beings would starve. This is, indeed, a claim about the beneficial empirical consequences of private property, but it has no conceivable relevance to Cohen's nonconsequentialist attack on libertarianism. It is a non sequitur in two senses. First, private property is not equivalent to libertarianism; we would not starve if - as is now the case-our private property were heavily taxed and regulated. Second, one cares about human starvation only if human happiness, or the alleviation of human misery, 
is one's ultimate end; but Cohen is not discussing what form of society will alleviate human misery, because that is not what libertarian philosophers claim is the merit of libertarianism. Rather, they claim that libertarianism is just because it uniquely embodies self-ownership or freedom, regardless of the empirical consequences of making these values paramount. By falling back on consequentialism to defeat Cohen's nonconsequentialist argument, Palmer's, Epstein's, and Feallsanach's use of Locke is a perfect example of libertarian straddling. (Feallsanach [1998, 32I] alone recognizes the problem, but his solution is to assert, without explanation, that "consequences are appropriate material for the intuition to work on, even for a deontological moral theory." Admittedly, philosophers often proceed as if their intuitions about consequences are relevant, but this cannot justify the practice of erecting deontological superstructures atop these consequentialist foundations.)

The heart of my article was the suggestion that conscientious libertarians, such as Boaz, find themselves unable to stop their straddling because neither consequentialist research nor nonconsequentialist philosophizing succeeds in credibly delivering the libertarian conclusions they desire. Combined with each other, however, the two forms of reasoning, a priori and a posteriori, appear to achieve this end. By shifting back and forth between social science and philosophy, one can (inadvertently) obscure the failure of either approach to justify libertarian conclusions.

At the end of my article, I elaborated a specific form of "postlibertarian" consequentialist research that could end the straddling and revive the Enlightenment aspiration to investigate the social world with an open mind in the hope of improving life on earth. Anyone who paid attention to its last quarter would therefore have had to realize that the purpose of "What's Wrong with Libertarianism" was, despite the provocative title, constructive. However, to demonstrate the need for a "postlibertarianism," I had to devote the first three quarters of the essay to establishing the seriousness of the problems with libertarianism. Unhappily, Palmer sees only this negative aspect of the essay, ignoring its positive dimension, and he reacts in just the ideological spirit I was urging libertarians to abandon. Moreover, Palmer not only fails to refute my account of libertarian straddling; he tends to confirm it, both in his defense of the libertarian view of "freedom" (see Part II below) and in his failure to provide the slightest reason to conclude that, according to 
the standards of the hypothetical imperative that he now embraces, one should reach libertarian conclusions (see Part I).

Before substantiating these contentions, let me say something about the mode of "What's Wrong with Libertarianism" and of the present Rejoinder. Both articles are forms of intellectual history. That is, they try to do more than simply identify logical mistakes (in this case, mistakes in libertarian thought), for they are attempts to explain why the same rather obvious mistakes get made over and over again. Palmer (I998b, 343) bristles at this form of analysis, asserting that it somehow amounts to a "demeaning and personal attac $[\mathrm{k}]$ on ... the motives of libertarian writers." But intellectual history is an inevitable and, I believe, a valuable part of Verstehen. Attempting to understand not only what someone is doing, but why he may go wrong in doing it-even with the best of motives-is an inherent task not only of the social sciences but of daily life (see Hayek 1948). But, in the attempt, we have to go a little deeper than the overt intentions of those we are trying to understand. Otherwise, we would never be able to explain (as opposed merely to identifying) their errors, and therefore would never achieve the goal of understanding. If we fail to go deeper than motives, we will have to attribute error to mendacity-as Palmer incorrectly assumes I am doing-; or we will have to think of those with whom we disagree as making their (putative) errors out of stupidity; or else we will have to consider their errors unintelligible, as if those who made them were perverse automatons who cannot really be understood by other human beings. ${ }^{5}$ These alternatives, it seems to me, are far more disrespectful than is the practice of intellectual history.

A different way of putting the point is to say that if we are to understand those with whom we disagree, we must go beyond their conscious motives and examine the subconscious impulses to which their ideas and assumptions may commit them. ${ }^{6}$ As Weber $(1978,9)$ put it, "'conscious motives' may well, even to the actor himself, conceal the various 'motives' and 'repressions' which constitute the real driving force of his action." In going deeper than motives, or in going deeper than conscious motives, one does not demean those whose mistakes one is discussing; on the contrary, one pays them the compliment of empathatic understanding. Whether this understanding ends up being subjectively insulting to those whose errors are being discussed depends, of course, on their temperament, and this cannot be helped; whether it ends up being objectively insulting, however, depends solely on the accuracy of the understanding. Palmer, however, seems to believe that it is 
But I wonder if this is a club of which he really wants to be a member, since, even while he now maintains that libertarian conclusions are sustainable only for consequentialist reasons, his Reply mentions no such reasons, and it fails to answer a single one of my specific criticisms of the reasons, offered in their social-scientific moments, by Boaz, Murray, and David Conway-who, between them, draw on every consequentialistlibertarian argument extant at the end of the twentieth century. My point was not merely that libertarians should abandon their overt nonconsequentialism; it was that because they have not yet done so, their consequentialist social science produces libertarian conclusions precipitously where none are justified-because they covertly continue to believe that libertarianism is just, regardless of its consequences. In response, one cannot very well defend libertarian conclusions, as Palmer tries to do, merely by maintaining that modern libertarianism is consequentialistic (even if this were true, which it is not). One must further present some reason for thinking that consequentialism will yield libertarian conclusions. Otherwise, we are back, in practice, to a libertarianism that "brings together" moral imperatives and consequences by using moral imperatives to fill in the gaps when empirical research fails to do the job, and by using empirical research to lend plausibility to conclusions that most people find unacceptable when reached by means of categorical moral imperatives.

Palmer contends that consequentialism is best practiced at the level of rules or systems of rules rather than at the level of individual actions. I agree wholeheartedly. ${ }^{8}$ But Palmer does not give us any grounds for believing that, practiced at the level he and I prefer, consequentialism does lead to libertarianism. What reason have we to think that rules which treat people as if they have inviolate private property rights, rules. which therefore bar any form of intervention or redistribution, will contribute more to "peace, prosperity, cooperation, knowledge, social harmony, etc." (Palmer 1998b, 34I) than rules allowing the regulation and redistribution of private property-as do the rules of modern social democracies? It bears repeating that private property, which Palmer quotes Hume as defending, is not the same thing as undiluted private property. What is at issue when the topic is consequentialist libertarianism is not the benefits of private property or of the rule of law per se, but the benefits of rules that protect absolute private property.

The gravamen of the first section of my article (Friedman 1997, 409-26), plus a later subsection entitled "Orthodox Consequentialism" (ibid., 439-42), was that the consequentialist arguments we get from the 
likes of Murray, Boaz, and Conway (including such favorites of Palmer's appendix as public-choice and spontaneous-order arguments) do not justify absolute private property with any degree of adequacy. Palmer now says not a word in defense of these or any other specific consequentialist arguments for libertarianism. ${ }^{9} \mathrm{My}$ article was not about some inaginable or logically possible defects in libertarian consequentialism. Rather, I pointed to (what I claimed are) fatal flaws in every major variant of real, existing consequentialist libertarianism-fatal flaws, that is, in consequentialist libertarianism as we know it (to the extent that it is present) in the works of Buchanan, Tullock, Hayek, Murray, et al., and as reflected, in turn, in the books by Boaz, Conway, and Murray that I was discussing.

Half of the libertarian straddle involves the deployment of spontaneous-order, public-choice, and other specific consequentialist claims as grounds for antigovernment conclusions (which these claims cannot, however, sustain without the assistance of deontology). In this moment, deontology licenses (in the minds of putatively consequentialist libertarians) the doctrinaire thinking that is reflected in the leaps of logic and propagandistic tone typical of so much libertarian social science. ${ }^{10}$ For Palmer to respond to my argument about the way the libertarian straddle taints libertarian consequentialist scholarship merely by contending that, in theory, a consequentialism pitched at the level of rules or systems of rules could justify libertarian conclusions is another non sequitur. I nowhere disputed the point. What I disputed is whether, in fact, consequentialist libertarians have successfully justified libertarian conclusions. This is the challenge any consequentialist libertarian who chooses to engage with "What's Wrong with Libertarianism" would have to meet, but Palmer, depite his self-proclaimed consequentialism, seems entirely uninterested in it.

It seems plausible that this huge anomaly in Palmer's Reply may confirm my description of the differences between the libertarian and the postlibertarian mindsets. Although Palmer will now accuse me of attacking his motives, some attempt to analyze them is necessary if we are to understand why Palmer, the declared consequentialist, does not act consistently with this declaration. It is my claim that the libertarian straddler is interested, at best, in going through the motions of empirical investigation in order to reach predetermined conclusions. Such a claim may be "uncharitable" (Palmer I998b, 350), but-as I argued in my essay-it has the advantage of empathetic verisimilitude. Palmer's consequentialism purports to reach libertarian conclusions without any 
rigorous demonstration (indeed, any demonstration at all) that libertarianism actually would produce good results. One is moved to wonder about a version of consequentialism that displays so little interest in empirically demonstrated consequences-a political philosophy that is supposed to issue in a hypothetical imperative, but that does not bother to argue for the posited hypothetical. One may reasonably conclude, it seems to me, that Palmer's Reply itself exemplifies the libertarian straddle. This gives it broader relevance.

\section{WHAT'S FREEDOM GOT TO DO WITH IT?}

To find decisive evidence for this "uncharitable" interpretation, we need only look to the second half of Palmer's Reply. Here, Palmer defends (I) the liberal assumption that freedom is intrinsically (and supremely) valuable; (2) the classical liberal insistence that true freedom is negative freedom; and (3) the libertarian equation of negative freedom with absolute private property rights. I had contended that all three of these moves are illegitimate. Before examining the details of Palmer's response, however, we might ask ourselves: Why does he defend these moves at all?

Palmer's larger claim, remember, is that libertarian thinkers do not shift back and forth between teleology and deontology; my contention that they do is, according to Palmer (I998b, 34I), nothing but a vicious libel, for I have failed to understand that libertarian moral claims are based on the "good consequences" of capitalism. But what do the three moves Palmer is now defending have to do with good consequences? Combined, these moves (if valid) show not that laissez-faire capitalism is conducive to "life, prosperity, peace, cooperation, knowledge, social harmony, etc.," (ibid.), but that laissez-faire capitalism-cum-negative-freedom is intrinsically valuable, regardless of its consequences. The inherent justice of capitalism follows tautologically, with no empirical investigation necessary. Why, then, does Palmer the hypothetical-imperative advocate spend fully half of his Reply defending these three moves? If the libertarian, laissez-faire capitalist version of freedom is equivalent to negative freedom, and if negative freedom is intrinsically and supremely valuable, then we should be libertarians regardless of what social science tells us about the consequences of libertarianism.

In short, contrary to his protestations, it would appear that Palmer's libertarianism-orthodox libertarianism-is not consequentialist after all. If libertarianism is just, regardless of its consequences, then it need 
not concern Palmer that I have rebutted the extant arguments for its good consequences; and he need not bother to provide alternative arguments to the same effect. He can pronounce in favor of the theoretical possibility of a sound form of consequentialist libertarianism without worrying about whether it actually exists, and without so much as speculating about what might justify its laissez-faire conclusions. For, at bottom, none of that is very important: no matter what its consequences, after all, laissez faire instantiates negative freedom, and negative freedom is all-important. Thus, all the abstract talk of consequences functions (unintentionally) as ... propaganda. What really makes libertarianism valid is its embodiment of human freedom.

If this analysis is correct, then, as an illustration of the libertarian straddle, Palmer's Reply could hardly be bettered.

\section{FROM LIBERALISM TO CLASSICAL LIBERALISM TO LIBERTARIANISM, A PRIORI}

Now let me discuss, in turn, the specifics of Palmer's defenses of the intrinsic value of freedom, the equation of freedom with negative freedom, and the equation of negative freedom with absolute private property.

The intrinsic value of freedom was the subject of only one paragraph and one end note in my article (Friedman 1997, 427 and 465nII) - the topic of which was, one should remember, what's wrong with the libertarian form of liberalism, not what's wrong with liberalism in general (which would require a much longer treatise [e.g., Friedman 1999]). Still, there were those two brief discussions, with which Palmer's several pages of rebuttal never manage to come to grips. ${ }^{11}$ In marked contrast to Palmer's hands-off approach to demonstrating that libertarianism would produce good consequences, however, here he is nothing if not energetic, devoting more than a quarter of his article to defending this nonconsequentialist claim.

I argued that the problem with conferring intrinsic value on freedom is expressed in the "right to do wrong." This so-called right entails, I wrote, that "it is intrinsically valuable to be able to do what is valueless" (Friedman 1997, 465nIr). Palmer's first response is a lecture on logical contradiction, but his lecturing begs the question. The question I asked is not the one Palmer's logic textbook allows him to answer: whether "It is good to do X" is verbally the same as "It is good to be allowed to do X" (Palmer 1998b, 347). I was asking why we should be allowed to 
do what is bad; that is, why we should have a right to do something that, being wrong, we should not do. Palmer's claim (I998b, 348) that there is an "all-important" difference between doing something bad, on the one hand, and, on the other, being allowed to do something bad, such that there is no prima facie contradiction in the "right to do wrong," takes for granted the very liberal assumption-that there is something worthwhile about being allowed to do what is worthlessthat is at issue.

Palmer's next response to my questioning of the intrinsic value of freedom is equally beside the point. He contends ( $1998 \mathrm{~b}, 349)$ that freedom of the will exists and "is at the foundation of the entire libertarian tradition," contentions I would dispute only by replacing the word libertarian with the broader term liberal. Palmer devotes an enormous amount of space to condemning me for denying the existence of free will, but it was its value, not its existence, that I denied. Unfortunately, Palmer, like his liberal predecessors, proceeds straight from the existence of free will to its value, providing no more basis for doing so than the following two sentences:

As human beings we are rational creatures capable of choice and therefore capable of being held accountable and responsible. The exercise and development of this capacity is intrinsically valuable. (Ibid, 350)

The first sentence is a non sequitur, since the existence of free will was never at issue. The second sentence begs the question that is at issuewhich is precisely whether free will is, in truth, intrinsically valuable. The only way to connect the first sentence to the second is by committing still a third mistake, the naturalistic fallacy. The fact that we have free will no more makes its exercise good than the fact that we are mortal makes death good.

Palmer does well, however, to remind us of the connection in liberal thought between the existence of free will and the value of its exercise-no matter how illogical this connection is-because if freedom of action is valuable because it allows the exercise of freedom of the will, then one is led to endorse a "positive" view of freedom-meaning, in this context, a view of freedom as "doing whatever I want to do," i.e., freedom to do what I will-which is the very type of liberty Palmer, in his defense of negative liberty, condemns as "license." It is to actualize positive freedom (in this sense of the term) that contemporary liberals, 
such as the Rawls of $A$ Theory of Justice, emphasize the need to ensure that, as much as possible, everyone should have the means to do what they wish. Consequently, contemporary liberals tend to favor the egalitarian redistribution of property, contrary to the tenets of what is called "libertarianism"- yet they do so because they believe in exactly the thing that Palmer has just told us is the heart and soul of the "libertarian" tradition: the normative commitment to free will and, hence, free action. It is not $I$, as Palmer claims, who "plump[s] for 'positive' freedom" (I998b, 345); ${ }^{12}$ it is the despised left-liberals of the "Harvard faculty lounge" (ibid., 346)-because, as it turns out, they are better libertarians than Palmer is. They are the ones who take seriously Palmer's commitment to liberty of action as a manifestation of the allegedly intrinsic value of liberty of the will, and who want to ensure liberty of action for all by making available to all the means-the property-with which we may do what we will. The real question is why Palmer and his fellow "libertarian" philosophers oppose property redistribution, given their devotion to freedom of the will.

The answer is, of course, that they insist that the only "real" liberty is the negative kind: freedom from coercion. The negative definition, they insist, is the "correct" one. Palmer (I998b, 344) defends this move on the ground that "we already have a good word to denote ability. It's 'ability." What is supposed to follow from this? Why shouldn't "liberty" be defined in such a way that it is synonymous with "ability," when it is the ability to do as one wills that is, by Palmer's own argument, the valuable form of liberty? Palmer's logic textbook tells us that "definitions are tools of the mind" (ibid.). If our definition of the word liberty, or of freedom, is a tool designed to help us determine what kinds of actions constitute "the exercise and development of [free will, which] is intrinsically valuable" (ibid., 350), then the fact that this tool happens to be similar to, or even identical with, another one, the word ability, is irrelevant.

But, I must admit, to reach this conclusion I have juxtaposed Palmer's argument for the intrinsic value of freedom against his argument-six pages earlier-for the negative definition of freedom. It never occurs to Palmer that his own argument about the value of freedom should make him a proponent of its positive definition. Instead, when he considers the question of defining freedom, he uses a quite different criterion of a good "tool" than that it should express the allegedly intrinsic value of free action. Rather, he assserts, the definition should "distinguish between different kinds of actions" (I998b, 344). He seems to think that 
kinds of actions sort themselves out naturally, as if we find one "kind" of action lying on the ground, another flying through the air, and conclude automatically that they require two different words, such that if "ability" applies to one, then "freedom" must apply to the other. Obviously, however, this is not the way philosophy should proceed.

What makes for different "kinds" of actions when we are doing normative philosophy will be determined by whatever it is that we take to be good about actions (or their consequences). The question raised by Palmer's own apotheosis of free action, then, is why freedom from coercion should be considered a different "kind" of the same thing-freedom-as action that is freely willed. Neither Palmer nor any other libertarian has given us a reason to think that freedom from coercion is (intrinsically) valuable, as freedom of action supposedly is. Thus, to insist on the negative definition of freedom is to create a useless tool, and to repudiate the positive definition is to throw away a useful one. More important, the insistence on the negative definition of freedom substitutes for any argument as to why, if freedom of action is intrinsically valuable as an expression of freedom of the will, freedom of action isn't the kind of liberty we should aim for, even if it means coercively equalizing people's property holdings. (A connected problem, too obvious to labor, is that the inclusion of "coercion" in the definition of negative "freedom" makes the definition completely indeterminate, since coercion is simply the antonym of freedom. $)^{13}$

The basis of the "libertarian" resistance to "positive liberty" is, then, like Hayek's resistance to "social justice," entirely verbal: "That's not what liberty 'really' means." However, contained in this bit of (yes) Scholastic essentialism is something much worse: an illicit borrowing of the normative force derived from the positive-libertarian argument about the intrinsic value of free will. First (speaking logically, not historically) liberals argue, as Palmer does, for the value of free will and the type of action it produces; then they attach the words freedom and liberty to that type of action, lending these words normative luster; but then "libertarians" want to retain the normative luster produced by the argument from free will while abandoning its positive-libertarian, egalitarian implications. It can't be done-at least not coherently. The normative weight liberals attach to freedom pushes them in the direction of positive liberty for all; when "libertarians" narrow the definition of liberty so as to resist this impetus, they deprive liberty of its normative appeal.

Finally let us consider the question of whether, even if freedom is intrinsically valuable, and even if the only type of freedom that is intrinsi- 
cally valuable were freedom from coercion, a "libertarian" society would be the upshot, in that such a society should be thought, a priori, better to protect negative liberty than any other. I argued that it should not, because all societies must enforce some distribution or another of liberties and property, and all such enforcement is, at bottom, equally coercive. (One thing Sciabarra [1998, 293], like Palmer, fails to recognize is that "guns" always constrain us, in every form of society, to respect that society's distribution of power and resources.) This does not, as I noted, mean that there is no difference in the amount of freedom people have in different societies; but the difference is not in the amount of coercion that will (in theory) confront them if they violate the legal distribution of property and power. Instead, the difference is in the extent to which that distribution allows one to do what one wants-i.e., the difference is in the amount of positive, not negative, freedom. Thus, I noted, a libertarian society would probably produce a distribution of power, including power over property, that is more egalitarian than a real-world Communist society, in that, in a libertarian society, the state elite would have less positive freedom than it would under Communism, while the general populace would have more. (By the same token, a social democracy would, in theory, spread power, including power over property, even more widely, reducing the positive freedom of those who would be relatively rich in a libetarian society, but increasing the positive freedom of those who would be poor.) But the amount of negative freedom available to everyone is exactly the same in the two societies, since "it is as true of Communism as of libertarianism that, so long as I obey the coercively enforced allocation of property titles, 'no man or body of men," as Isaiah Berlin put it, " "interferes with my activity." " I concluded that "what varies between the two societies is the scope of this area, the size of the private sphere ... not whether its borders are coercively enforced" (Friedman 1997, 430).

In response, Palmer tosses his logic textbook out the window, substituting for the nominalist view that definitions are "tools of the mind" the view that, instead, they are tools of conventional wisdom. If the conventional wisdom tells us, for instance, that Canada in 1944 must have been freer in every sense than Nazi Germany, then I must be wrong to suggest otherwise. So Palmer need not mention exactly what it is that made Canada not only more positively free (meaning that most people could do more of what they willed), but more negatively free, than Germany: is it not obvious that Germany was more coercive? Notice that Palmer has unwittingly repeated my own comparison of two 
societies, substituting Nazi Germany for the Communist society, and Canada for the libertarian society-but that he somehow concludes that the very example I used, altered only in the locales, shows that negative liberty does vary across different societies, even though he never rebuts my analysis of how the example actually shows the opposite. Palmer simply ignores my argument that what the example illustrates is that "I have more positive liberty under a libertarian [or Canadian] than a Communist [or Nazi] regime: more liberty, that is, to 'attain a goal' of my own choosing (Berlin 1969, I22)" (Friedman I997, 430). Similarly, in raising the example of rape, Palmer never explains what makes this crime more coercive (as opposed to worse) than resistance to it, even though both the rapist and the resister equally use physical restraint or the threat of violence: the rapist against his victim, the victim against the rapist. Palmer's argument is, again, merely an outraged appeal to "common sense": "Freedom is slavery, after all!" (Palmer I998b, 345). In this respect, as in so many others, Palmer's Reply is depressingly representative of libertarian thinking (cf. Flew 1992 and Narveson 1992).

Palmer's only attempt to come to grips with my argument here occurs when he mentions that in capitalist societies, private property "is largely respected on the basis of custom, morality, and reciprocal respect" rather than coercion (Palmer 1998b, 345). But this proves only that a society in which people willingly obey the laws needs to employ less coercion to enforce them than one in which people are disobedient, which is no defense of libertarianism at all. A Communist or Nazi society in which most (but not all) people customarily obeyed redistributive or anti-Semitic laws without being forced to do so by the police would, on Palmer's account, qualify as more libertarian than a society in which most people had to be fined for parking violations.

Palmer's mistake is to confuse the means of enforcing the law with the law's content. It is in the content of libertarian laws, not in the number of times that people break them, that they differ from other types of law. Now it is not in prohibiting murder, rape, or even theft that the content of libertarian laws differs from that of the laws of other types of society. Libertarian laws differ from the laws of a social democratic or, for that matter, a Communist or Nazi society not so much in what they prohibit-i.e., any unauthorized rearrangement of legally validated entitlements - but, instead, in how they consider those entitlements to be distributed. It is not that the category of "theft" does not exist in a Communist, fascist, or social-democratic society; it is that 
what counts as the "property" that is protected against theft differs. In "What's Wrong with Libertarianism," I called this difference the question of the property "baseline" each type of society takes as legitimate. In a social democracy, the baseline, i.e., the set of legally enforced entitlements, is shaped, at least in part, by some type of egalitarian norm, while in a libertarian society the baseline is whatever pattern evolves spontaneously from people's mutual exchanges. It is tempting-and it is commonsensical, for people who grew up in capitalist societies- to see the libertarian baseline as less coercive than the social-democratic one, but that is the point of calling them both "baselines": they are the starting points of legitimacy, so it would beg the question to see social democracy as forcing its egalitarian pattern on a people who are inclined to resist such laws any more than a libertarian pattern (or non-pattern, if you will) would be forced on a people who refused to obey libertarian laws. Both societies will (in principle) just as coercively impose their baselines on people if people choose to violate them. While the libertarian "pattern" evolves out of mutual exchanges, these are exchanges of property whose ownership is every bit as coercively established and protected as are the "re-"distributions upon which social democracy relies.

As I showed at some length, "if we start from a social-democratic baseline, it is libertarianism that sanctions coercive aggression: coercive aggression against the persons or property of those who are deprived, say, of their welfare entitlements by the refusal of a libertarian government to enforce them" (Friedman 1997, 429). Only if one begs the question by taking the libertarian baseline to be "natural," and thus anterior to political establishment and enforcement-say, by adopting the Lockean doctrine of the metaphysical magic of labor mixing-can one avoid this reasoning.

\section{WHAT POSTLIBERTARIANISM IS NOT}

One problem with libertarian philosophy is that it is a primitive and rightly superseded form of liberalism, where "liberalism" means a commitment to individual freedom. Most liberals have come to recognize that if freedom of action is good, it may, in theory, require the redistribution of property. The libertarian insistence on the negative definition of freedom is simply a "naive and unreflective" (Palmer 1998b, 352n3) 14 attempt to avoid this conclusion. A second problem is that the notion that negative freedom is, by definition, better protected by libertarian- 
ism than social democracy is even more naive and unreflective, grounded as it is in the illusion that the kind of (largely private) property distribution to which we are accustomed is more natural and less coercive than any other. A third problem with libertarian philosophy is that it is a species of liberal philosophy, which maintains (with the exception of utilitarian liberalism) the intrinsic goodness of the ability to do what is bad.

Libertarianism, however, contains within it the resources to overcome all of these problems. These resources can be found in the very thing that leads to the libertarian straddle: the yoking together of deontological and consequentialist reasoning. If libertarians would simply reflect on the matter, I believe they would conclude that it was not due to a belief that freedom-cum-private property is intrinsically valuable that they first became libertatrians; instead, what motivated them was a belief that laissez-faire capitalism would be good for people because it would relieve misery and social conflict. Now this is exactly the type of consequentialist reasoning that originally produced liberalism itself: in the Wars of Religion, the protoliberal politiques pioneered the thought that tolerating the bad (i.e., heresy) would serve a larger good (i.e., civil peace). But the temptation to absolutize this hypothetical, disputable version of liberalism by shifting its basis to a priori individual rights and the intrinsic value of freedom occurred so long ago that the consequentialist nerve of liberalism is, by now, nearly dead. Not so with libertarianism, which got its start a mere half-century ago in consequentialist economics. Economics is still very much alive in libertarian thought, albeit often corrupted by the incursions of libertarian philosophy. What my article proposed is that libertarians disentangle the two strains of thought, recognize the fatal defects of the philosophical strain, and return to the consequentialist impulse that gave birth to their movement in the first place. This would end the need for Scholasticism about the "right" definition of freedom, for naiveté about the coerciveness of a libertarian society, and for self-contradictorily praising as intrinsically good the ability to do what is intrinsically bad-since it is a desire to maximize the good in a world of imperfect people that leads libertarians, like the early liberals, to want to allow people to do the bad to begin with.

But moving beyond these conundrums would require more than lipservice to some conceivable form of consequentialism: it would require ruthlessly repudiating the libertarian straddling of the past 50 years and, even more importantly, accepting the possibility that as a result, libertar- 
ianism will not be sustainable. The bottom line of consequentialism is to instrumentalize one's politics to the achievement of whatever one takes to be the good, and if libertarianism turns out not to be conducive to the good, then libertarianism would have to be rejected.

"Postlibertarianism" refers to any consequentialist research that is self-consciously directed toward some good other than the empty and self-contradictory good of liberty. Postlibertarian research may well conclude that (positive) liberty is instrumentally valuable, whether because, in the form of civil freedom, it leads to civil peace; or because, in the form of economic freedom, it leads to prosperity. It may also conclude otherwise. By the same token, postlibertarian research may be undertaken by anyone, of any background; but because the tension between deontology and consequentialism is so much fresher and closer to the surface among libertarians than among mainstream liberals, it seems likely that a disproportionate number of self-conscious consequentialists will be former libertarians. Hence the prefix in "postlibertarianism."

I hope it is clear, then, why I believe that Chris Matthew Sciabarra has fundamentally misunderstood postlibertarianism. Postlibertarianism is not a fancy term for a new strategy (such as the appropriation of postmodern hermeneutics) ${ }^{15}$ for achieving the libertarian and liberal aspiration to "liberate humanity," as Sciabarra (1998, 294) implies. It is, on the contrary, an abandonment of that aspiration, necessitated by one's recognition, inter alia, of the philosophical incoherence of treating freedom as an intrinsic value. This is something that Ayn Rand not only failed to recognize, but positively obscured-by putting together one of the first, and by far the most successful, of the ideologies of libertarian straddling.

It is possible that a given postlibertarian will conclude that "freedom and individualism" (Sciabarra 1998, 294) are conducive to, say, happiness; and it is possible, as I suggested at the end of "What's Wrong with Libertarianism," that postlibertarians will find, in the demagogic character of mass politics, both echoes of Rand and consequentialist reasons to restrict the power of the modern state. But a postlibertarian would first have to investigate whether "freedom and individualism" are, in fact, conducive to happiness, or whether they might not, instead, lead to anomie and misery; and she would have to inquire into the actual extent and effects of demagogic mass politics. While the power of Rand's novelistic dystopias stems from her depiction of the allegedly disastrous consequences of the megastate and its demagogic cultural context, her 
philosophy obviates the investigation of such consequences by trumping any consequentialist considerations with a doctrine of absolute "rights," and, as well, by branding as immoral "collectivism" a concern for the consequences of state action for anyone but oneself. She fails to recognize that her own defense of every "man's rights" is itself collectivistic and altruistic, as is her concern for the dystopian consequences of demagogic politics. Her consequentialism is, therefore, even more confused and short-circuited by nonconsequentialist commitments than is the consequentialism of other libertarian or semilibertarian ideologues, such as Hayek and Rothbard.

That Rand's defense of the intrinsic value of "freedom and individualism" can be couched as a concern for the "deleterious effects" of "statism" on "the subject's consciousness and behavior" (Sciabarra 1998, 295) hardly qualifies Rand as a genuine consequentialist, since "human agency" (i.e., freedom of the will, as manifested in freedom of action) is the criterion against which these effects are judged deleterious (ibid.). With Rand and Sciabarra, therefore, as with all deontological liberals, the only type of empirical investigation we need undertake is designed to expose "power relations" (ibid., 294), and we know in advance that such relations are bad in themselves, by definition. The differential effect of various types of power relations on human well-being is thus a nonissue. The only end to which social science can be instrumental, then, is the "good" of being able freely to choose one's own good-or bad. If this is consequentialism, there is no such thing as nonconsequentialism.

I concede that methodologically, Rand's emphasis on the cultural underpinnings of politics is an improvement over, say, dogmatic rational- and public-choice theory. But merely noticing that politics is connected to culture-the Randian form of "dialectics," which David MacGregor (1997) characterizes as "trivial"-is no substitute for breaking free from the anticonsequentialist fealty to freedom-cum-capitalism, which makes culture and politics but colorful backdrops to one's philosophy. Rand, just as much as any other libertarian philosopher, was dedicated to a political ideal that renders genuine consequentialist research, even into politics and culture, otiose. Even though Rand was clearly convinced by her experience in the Soviet Union that socialism was disastrous for human welfare (as distinct from libert $\gamma$ ), and even though this conviction came through in her novels, it is suppressed in her philosophy, as it is in all orthodox libertarianism, which is therefore free of the vicissitudes of empiricism. Rand's notoriously dogmatic per- 
sona, as much as Palmer's unresponsive and self-contradictory Reply, embodies the doctrinaire temptation that makes libertarian philosophy a betrayal of the inherently open-ended, open-minded concern for human well-being that inspired it and that might, conceivably, allow it to be transcended.

\section{NOTES}

I. Three examples. First, Palmer (1998b, 35I) claims that in describing as an instance of "bourgeois complacency" Charles Murray's one-paragraph "ruminations" on happiness (Friedman I997, 419, 421) -in which Murray equates happiness with taking actions for which "a substantial amount of responsibility rest[s] on your shoulders, whether in a moment (sinking the winning basket) or over many years (making a good living)" (Murray 1997, 32)-my article is uncharitable to Murray. Palmer overlooks the next sentence of my essay: "I am not suggesting that what Murray says should be disregarded because whatever is bourgeois, or brief, is vulgar" (Friedman 1997, 4I9). Indeed, I go on to say that "we" are all bourgeois, and that Murray is expressing what we are all likely to feel-hardly the way to defame someone. Finally, Palmer disregards the reasons I give for wondering if Murray's view of happiness is a product of bourgeois culture, and may therefore be less self-evidently irue than it seems. It is enough for Palmer that I used the word "bourgeois"-meaning that it is Palimer, not I, who considers this term an insult. Similarly, Palmer (1998b, 35I) accurately reports that I call Murray's view of community "facile," but he does not mention my extended argument justifying this conclusion (Friedman I997, 420-2I)-let alone does he rebut it.

Second, Palmer (1998b, 350, 35I) contends that I was "remarkably uncharitable" in "dismiss[ing]" Milton Friedman for having famously equated capitalism and freedom. Here Palmer does attempt a rebuttal, but it fails. He quotes two sentences from Friedman's Capitalisn and Freedom, of which the first, calling "freedom in economic arrangements ... an end in itself," tends to support my claim; and of which the second, dealing with "political freedom;" is irrelevant. If one reads the rest of the page from which Palmer pulls these sentences (Friedman 1962, 8), one will find that Friedman is arguing precisely that for most people (as distinguished from "intellectuals," who "tend to express contempt for what they regard as material aspects of life"), "the direct importance of economic freedom is at least comparable in significance to the indirect importance of economic freedom as a means to political freedom," such that the imposition on someone of a ro-percent income tax means the "deprivation" of "a corresponding part of his personal freedom." On the next page, Friedman lists a whole host of economic regulations that, he asserts, deprive people of "personal freedom." Strictly speaking, I should have said that Friedman equates capitalism with personal freedom, but this terminology does not affect in the 
least the substance of my objection: that Friedman contradicts his consequentialist approach to defending capitalism by placing intrinsic value on capitalismcum-("personal") freedom regardless of its consequences. Most importantly, Palmer fails to notice that this criticism of the great economist is a minor note in a section of the essay (Friedman 1997, 449ff) that lauds Chicago- and Austrian-school economists for their consequentialism, objecting only to their lapses into nonconsequentialist philosophizing. It is not a "dismissal" of Friedman at all.

Third, Palmer (1998, 352n4) claims that I "misinterpre[t]" David Boaz's defense of individualism, but he never even hints at what this misinterpretation is. Instead he reiterates Boaz's defense of individualism and argues, correctly, that (if sound) it constitutes a rejoinder to communitarianism. But Palmer's repetition of this rejoinder is a non sequitur: I was pointing out that, even if it is sound, there is no reason to think that Boaz's defense of individualism against communitarianism leads to libertarian liberalism rather than social-democratic liberalism. To make that leap one would, I pointed out, require-by virtue of Boaz's own argument about individuals' "'needs' "-empirical evidence Boaz never provides that laissez-faire capitalism better serves those needs than social democracy does (Friedman 1997, 437). Moreover, I argued at length (ibid., 437-38), Boaz's defense of individualism "is either inaccurate or trivial" (ibid.), for reasons that Palmer does not attempt to rebut.

2. It is rather strange, having published a 60-page article praising consequentialist social science and condemning the corrosive effects of deontological thought, to be informed that I am a Kantian who equates morality with categorical imperatives. This is the first of a string of unwarranted misreadings of the text to which Palmer is attempting to reply, all of which appear to stem from Palmer's failure to consider the possibility that, in trying to understand even a minimally complicated argument, he might go wrong if he tears each point from its context. In this case, he seems to have focused solely on why I interpreted his allegedly hypothetical libertarianism as categorical. While this narrow question might be seen as credibly answered by Palmer's inference that I am assuming all morality to be categorical in nature, such an inference contradicts the consequentialist thrust of my argument as a whole. Indeed, even my brief condemnation of Palmer's libertarianism is based on what I perceive to be its failure to be consequentialist or hypothetical.

3. To recognize how strange Palmer's consequentialist interpretation of modern libertarian philosophy is, one need only consult the responses of Narveson (1992), Tibor Machan (1992), and Antony Flew (1992) to my earlier critique of libertarian deontology (Friedman 1990). Or one could consult the books of libertarian philosophy Palmer recommends in his appendix to The Libertarian Reader (Boaz 1997a) —or, indeed, the books by Boaz (1997b) and Charles Murray (1997) discussed at length in the review essay to which Palmer is replying.

4. A mildly attentive reading of "What's Wrong with Libertarianism" (esp. 453-54 and 456 ) would have alerted Palmer to the fact that there is a problem here, since I claimed the Enlightenment-hence Hume and Smith-as the progeni- 
tor of just the kind of postlibertarian thought I would like to see: consequentialist thought. Thus, I could hardly be unaware of the consequentialist tradition in philosophy of which Palmer makes so much; nor could I believe that philosophy must be nonconsequentialist, as he infers; nor could holding up the likes of Hume and Smith as exemplary, as he now does, indicate disagreement with me. What Palmer neglects to tell us is how his apotheoses of consequentialism and the Enlightenment prove that libertarianism is the upshot of these traditions.

5. This may explain why Palmer oscillates between treating his interlocutor as an idiot who requires lectures on elementary logic; an aider and abetter of crimes against humanity, such as Stalinism; and an unintelligible perpetrator of obvious contradictions, blindly unaware of the evident incoherence of his arguments. Had Palmer $(1998 b, 344)$ attempted to understand what I wrote, in context, before assuming that everything whose meaning was not immediately evident to him must stem from "logical and factual errors," he might not have ended up producing a laundry list of inaccurate and irrelevant criticisms. But such an attempt at understanding might have opened up the possibility that the incoherence and contradictions lie in libertarianism itself-not because libertarians are stupid, criminal, or unintelligibly prone to self-contradiction, but because they have simply made the mistake of failing to clarify in their own minds whether they think laissez-faire capitalism is intrinsically good, regardless of its empirical consequences, because it embodies "freedom" or inviolate property rights; or whether instead they think it is good because of jes empirical consequences.

6. To avoid misunderstanding, what I am calling intellectual history needs to be distinguished from other modes of attempted Verstehen. The intellectual historian does not claim access to the unconscious. Rather, as I see it, the intellectual historian's task is to discern what Popper would call the "problem situation" that (often subconsciously) faces a writer, based on the assumptions to which she has committed herself. The object of intellectual-historical analysis is texts, not people; intellectual history, while sometimes looking like the psychoanalysis of the authors of texts, is actually best conceived of as a structural analysis of the logic of the texts themselves-a logic that, however, originates in the conscious and subconscious (and, perhaps, the unconscious) mind of the author. This does not make the author the best authority about her logical motivations; we would not be satisfied if, in response to our analysis of why an author was driven by her assumptions toward an erroneous conclusion, the author simply denied the accuracy of the analysis without giving a better alternativeany more than we would be satisfied with such a denial in the case of our assessment of the thinking of an acquaintance or a politician we were trying to understand. To deny is not to falsify. But the textual focus of intellectual history does mean that the author of the text is as entitled as anyone else to practice intellectual history upon it by advancing hypotheses about its operative assumptions; indeed, a self-aware author will constantly do this, in the attempt to ensure that her text is not being driven toward bogus conclusions by unexamined or merely convenient premises. 
On the other hand, an author who lacks self-awareness may react to an accurate intellectual history of his thought with a burst of furious (and empirically unsustainable or logically inconsistent) denial, such as that evinced in Palmer's Reply. Like a Freudian, the intellectual historian may interpret denial as indirect evidence that her analysis is on the mark. But unlike unfalsifiable forms of Freudian (and Marxist, and public-choice) attempts at Verstehen, which automatically turn denial into evidence of what is being denied, the intellectual historian is entitled to interpret denial in this way only if the denial is not accompanied by sound empirical or logical reasons for thinking that the analysis in question is erroneous; reasons, in other words, that falsify the analysis.

7. Moreover, Palmer's appendix to Boaz fails ever to mention the potential conflict (or even the existence) of deontological and teleological approaches to libertarianism. This failure encourages the interpretation that Palmer was "bringing together" consequentialist and nonconsequentialist reasoning in the way libertarian thinkers usually do: by overlooking the tension between them. Indeed, the largely uncritical celebration of libertarian thought found in Palmer's appendix heaps encomia on thinkers who bring together the two forms of reasoning in just this illegitimate way. For example, on the page that immediately follows the one containing the "brings together" passage, Palmer $(1997,417)$ unabashedly recommends a book-Murray Rothbard's For a Nelv Liberty-that attributes the convergence between the conclusions of libertarian philosophers and those of libertarian social scientists to a "fortunate" happenstance (Rothbard 1976, 40; cf. Friedman 1997, 434-35). And the same page of Palmer's appendix $(1997,417)$ characterizes Robert Nozick's Anarchy, State, and Utopia as "brilliant," registering no objection to Nozick's failure to consider the empirical consequences of the libertarian rights he defends.

8. Palmer wastes a great deal of effort denying something I never affirmed: that people should be required "to act so as always to attempt to generate the best consequences" (Palmer 1998b, 34I). Apparently, when Palmer reads the word utilitarian (admittedly a label that is prone to misunderstanding, but so is the only alternative, eudaimonist), he feels entitled to conclude that I am speaking of the philosophy of Jeremy Bentham, despite the fact that nothing in my argument is Benthamite, and despite the fact that the rule-oriented thinkers on whom Palmer relies to knock down the Benthamite straw man (Hume and Hayek) are, themselves, with some justification, called "utilitarians." (Later, Palmer [ibid., 35r] quarrels with my use of the term utilitarian to describe Charles Murray, contending that this "obscures the difference between a consequentialist and a utilitarian," a difference upon which Palmer then delivers a mini-lecture. Palmer is mistaken. A consequentialist can favor any of a number of ultimate ends, among them happiness; a utilitarian, speaking generally, is a consequentialist who takes happiness to be the telos; and Murray repeacedly makes it clear that happiness is his [ostensible] ultimate end, as "What's Wrong with Libertarianism" demonstrates at length.)

9. This is not the only puzzling aspect of Palmer's alleged consequentialism. One would expect a consequentialist libertarian to rejoice at the discovery of a 
whole new line of inquiry into the possible irrationality of government policy, especially one that is (unlike spontaneous-order and public-choice theory) buttressed by a vast, rock-solid empirical literature. Just such a line of inquiry, embodied in the political-science research on public ignorance, is described at the end of "What's Wrong with Libertarianism" - but Palmer is completely silent about it. Perhaps, for some reason, he does not find this literature convincing, even though the scholars who have produced it (nonlibertarians all) have replicated its findings repeatedly (to their great discomfort; see Hoffman 1998). But, convinced or not, one would expect a consequentialist libertarian to be at least interested in it. So we are entitled to ask why Palmer ignores it. One possibility is that, unlike the arguments from spontaneous order and from public-choice theory (if they were sound), the public-ignorance literature cannot be thought to produce an airtight case for libertarianism. For example, as I pointed out (Friedman 1997, 456), the ubiquity of public ignorance leaves open at least the logical possibility of expert, and thus well-informed, government intervention. Where the postlibertarian consequentialist might find this literature compelling because it uses insights that (for reasons I describe in Part IV of "What's Wrong with Libertarianism") ring true to the experience of libertarians, she might also be attracted by its use of them in ways that stimulate the investigation of political reality, regardless of where the investigation may lead.

10. An instance of both logical leaping and propagandizing: Palmer's use of an innocent observation on my part-that libertarianism is both mainstream in its unreflective acceptance of the legitimacy of private property, and marginalized in its insistence that this legitimacy trumps all other considerations-as an occasion to wax indignant about the "libertarians" (sic) who "were murdered by communist, monanchist, fascist, national socialist, and other collectivist states" (1998b, 347). Another instance: Palmer's claim (1998b, 345) that G. A. Cohen defends "the communism . . . which rests on the constant exercise of terror against a subject population." This is slanderous: far from defending the exercise of terror under real, existing Communism, Cohen (like most Western Marxists) saw it as a perversion of the type of socialism he favored-as Palmer's own quotations from Cohen (ibid., $354 \mathrm{ng}$ ) unequivocally demonstrate.

1I. Instead of making any argument at all against my reasons for questioning the intrinsic value of freedom, Palmer (1998b, 347), in one of many attempts to wield erudition as a bludgeon, criticizes me for failing to cite the literature on "the right to do wrong," and he proceeds to quote from this literature ad nauseam, demonstrating nothing substantive, but managing to show that many other liberals have shared his viewpoint (one wonders whether his oft-cited logic textbook has no chapter on the illegitimacy of arguments from authority). It is poignant, however, that Palmer neglects what is, to my knowledge, the only contributions to this literature that are directly relevant: Jeremy Waldron's article on the subject, and the debate it sparked (Waldron 198I; Galston 1983; Waldron 1983). Waldron's article, unlike the sources Palmer quotes, attempts to grapple with the seeming incoherence of a "right to do wrong" rather than simply affirming that there is such a right. And, having directed our attention 
to this apparent incoherence, Waldron has little choice but to take as a given exactly what Palmer finds so ridiculous: that the right to do wrong is, indeed, prima facie contradictory. Waldron's task is then to explain how it is that liberalism seems to produce this contradiction, not to dispute that it is contradictory.

12. I "plump" for no brand of freedom, because for me, nothing rides on how we define the term. All that matters to me is which form of freedom, or unfreedom, produces the best consequences. The dispute over the "correct definition" of freedom lies entirely in the realm of deontology. My only role here is to point out the internal contradictions in libertarians' definition of freedom.

13. Nor will it do to define "coercion" as "the use of force," since then the question is what constitutes "force." Firing a gun at the side of "my" barn presumably does not, but firing it at the side of "your" head presumably does. But then what constitutes force collapses into whatever system of property defines this barn as mine and that head as yours. This is why there can be no difference between the amount of negative freedom protected by different systems of property, as I argue in the text below: negative freedom is nothing more than freedom from coercion, i.e., freedom from force, i.e., freedom from violations of the system of property in a given society.

14. Palmer (1998b, 352n3) uses these adjectives to characterize my opposition to nonconsequentialist libertarianism, for, as he contends, "what counts as a good or a bad consequence cannot by itself be determined by invoking consequentialism; there must be some deeper reflection . . . about what consequences we should seek to achieve or avoid." This is quite right, but I made the same point not once, but twice: see Friedman 1997, 43I and 460n2. In these passages I made it quite clear that consequentialist social science requires nonconsequentialist philosophy to tell it what type of consequences count as good ones. Opposing nonconsequentialist libertarianistm is not the same as opposing nonconsequentialist philosophy. The former is defective not because there is anything wrong, per se, with a priori philosophy, but because a priori philosophy cannot establish libertarian conclusions, as Part III of the present Rejoinder contends. Libertarian conclusions, if they are to be established, require a posteriori evidence that libertarianism would achieve ends that are established a priori as good.

IS. In order to endorse Kevin Quinn and Tina R. Green's (1998) critique of libertarian "hermeneutics," one need not accept their communitarian (and thus authentically postmodern-hermeneutic) alternative to it. To do so would mean substituting an incorrigible, omniscient discursive community for the incorrigible, omniscient individual to which they rightly object. Both communitarianism and deontological liberalism-including libertarian versions of liberalism-relativize the good, differing only on whether the good is whatever the individual or whatever the community says it is; both communitarians and deontological liberals thereby accept the view that there is some authority (whether the community or the individual) whose decisions are normative. (It is my criticism of the metaethics of normative authority in Friedman 1997, 427 that prompts Palmer's defense of the "right to do wrong." 
Friedman 1999 is a systematic critique of this metaethics, in both its communitarian and liberal forms.)

\section{REFERENCES}

Berlin, Isaiah. 1969. Four Essays on Liberty. New York: Oxford Univeristy Press.

Boaz, David. 1997a. Libertarianism: A Primer. New York: Free Press.

Boaz, David. 1997b. The Libertarian Reader: Classic and Contemporary Writings from Lao-Tzu to Milton Friedman. New York: Free Press.

Conway, David. 1995. Classical Liberalism: The Unvanquished Ideal. New York: St. Martin's Press.

Epstein, Richard A. 1998. "The Right Set of Simple Rules: A Short Reply to Schauer and Comment on Cohen." Critical Review 12(3): 305-18.

Feallsanach, Am. 1998. "Locke and Libertarian Property Rights: Reply to Weinberg." Critical Review 12(3): 319-23.

Feser, Edward. 1998. "Hayek, Social Justice, and the Market: Reply to Johnston." Critical Review I2(3): 269-82.

Flew, Antony. 1992. "Dissent from "The New Consensus': Reply to Friedman." Critical Review 6(I): 83-96.

Friedman, Jeffrey. I990. "The New Consensus: II. The Democratic Welfare State." Critical Review 4(4): 633-708.

Friedman, Jeffrey. 1997. "What's Wrong with Libertarianism." Critical Review II(3): 407-67.

Friedman, Jeffrey. 1999. Beyond Voluntarism: $A$ Critique of the Similarities between Libeval and Communitarian Thought. Ph.D. dissertation, Department of Political Science, Yale University.

Friedman, Milton. 1962. Capitalism and Freedom. Chicago: University of Chicago Press.

Galston, William A. 1983. "On the Alleged Right to Do Wrong: A Response to Waldron." Ethics 93: 320-24.

Hayek, F. A. 1948. "The Facts of the Social Sciences." In idem, Individualism and Economic Order. Chicago: University of Chicago Press.

Hoffman, Tom. 1998. "Rationality Reconceived: The Mass Electorate and Democratic Theory." Critical Review $\mathrm{I} 2(4)$ : forthcoming.

Lomasky, Loren. 1987. Persons, Rights, and the Moral Community. New York: Oxford University Press.

MacGregor, David. "It Ayn't Rand." Critical Review II(3): 373-92.

Machan, Tibor. 1992. "The Right to Private Property: Reply to Friedman." Critical Review 6(I): 97-106.

Murray, Charles. 1997. What It Means to Be a Libertarian. New York: Broadway Books.

Narveson, Jan. 1988. The Libertarian Idea. Philadelphia: Temple University Press.

Narveson, Jan. 1992. "Libertarianism, Postlibertarianism, and the Welfare State: Reply to Friedman." Critical Review 6(I):45-82. 
Nozick, Robert. 1971. Anarchy, State, and Utopia. New York: Basic Books.

Palmer, Tom G. 1997. "The Literature of Liberty." Appendix to Boaz 1997b.

Palmer, Tom G. I998a. "G. A. Cohen on Self-Ownership, Property, and Equality" Critical Review I2(3): 225-\$2.

Palmer, Tom G. 1998b. "What's Not Wrong with Libertarianism: Reply to Friedman." Critical Review 12(3): 337-58.

Quinn, Kevin, and Tina R. Green. 1998. "Hermeneutics and Libertarianism: An Odd Couple." Critical Review 12(3): 207-24.

Rothbard, Murray N. 1978. For a New Liberty:The Libertarian Manifesto, rev. ed. New York: Macmillan.

Samuels, Warren. 1993. "The Growth of Government." Critical Review 7(4): 445-60.

Sciabarra, Chris Matthew. 1998. "Are We All Dialecticians Now? Reply to MacGregor and Friedman." Critical Review I2(3): 283-98.

Waldron, Jeremy. I981. "A Right to Do Wrong." Ethics 92: 2 I-39.

Waldron, Jeremy. 1983. "Galston on Rights." Ethics 93: 325-27.

Weber, Max. 1978. Economy and Society, vol. I, ed. Guenther Roth and Claus Wittich. Berkeley: University of California Press.

Williams, Juliet. 1997. "On the Road Again: Hayek and the Rule of Law." Critical Review II(I): IOI-I2O. 